У, $\triangle \mathrm{K} 346: 368.4$

ББК 65.272

DOI 10.22394/1682-2358-2018-6-66-71

K.A. Bogma, Candidate of Sciences (Siciology), lecturer of the Secondary Vocational Education Department, South-Russian Institute of Management, Branch of the Russian Presidential Academy of National Economy and Public Administration

K.D. Belovodchenko, postgraduate student of the Political Science and Ethnic Policy Department, South-Russian Institute of Management, Branch of the Russian Presidential Academy of National Economy and Public Administration (email: international@uriu.ranepa.ru)

\section{SOCIAL ASSESSMENT OF OPTIMIZATION LIMITS FOR CITIZENS' PENSION SAVINGS}

The current state of the pension system in the Russian Federation in the socio-political discourse is analyzed. According to the results of the study of the methodology for the formation of pension payments, the consequences of cognitive dissonance caused by the discrepancy between expectations of the authorities and management, and the reality faced by future and current pensioners are revealed.

Key words and word-combinations: power, management, pension provision, citizens, social policy.
К.А. Богма, кандидат сочиологческих наук, преподаватель отделения СПО ЮжноРоссийского института управления - филиала Российской академии народного хозяйства и государственной службь при Президенте РФ (email: socpol@uriu.ranepa.ru)

К.А. Беловодченко, аспирант кафедрь политологии и этнополитики Южно-Российского института упраһления - филиала Российской академии народного хозяйства и государственной службы при Президенте РФ

(email: international@uriu.ranepa.ru)

\section{СОЦИААЬНАЯ ОЦЕНКА ПРЕАЕ АОВ ОПТИМИЗАЦИИ ПЕНСИОННЫХ НАКОПАЕНИЙ ГРАЖААН}

Аннотация. Анализируется современное состояние пенсионной системы в Российской Федерации в социально-политическом дискурсе. По итогам исследования методики формирования пенсионных выплат выявляются последствия когнитивного диссонанса, вызванного разногласием между ожиданиями, исходящими от органов власти и управления, и реальностью, с которой сталкиваются будущие и настоящие пенсионеры.

Ключевые слова и словосочетания: власть, управление, пенсионное обеспечение, граждане, социальная политика.

B Всеобщей декларацией прав человека 1948 г. (ст. 22) опредемяется право каждого человека в цивилизованном государстве на социальное обеспечение. Пенсионное 
обеспечение явмяется основной составцяющей системы социальной защиты населения. Совершенствование пенсионной системы России на законодательном уровне происходит путем внесения изменений в законодательные акты, касающиеся решения вопросов о назначении и выплат пенсий, а также в Бюджетный, Уголовный и Трудовой кодексы Российской Федеращии [1-4] . Пенсионная система Российской Федерации сегодня переживает весьма непростые времена: вопрос об изменении пенсионного возраста, волнующий многих гражАан, решен в сторону его увеличения Аля женщщин с 55 Ао 60 мет, Аля мужкчин с 60 - Ао 65 мет. Безусловно, реформа пенсионной системы Российской Федераџии назревала давно, с каждым годом все более очевидным становияся разрыв между ожиданиями пенсионеров, планами Минфина и реацьностью.

Президент РФ назвал причины повышения пенсионного возраста: сокращение уровня соотношения работающих гражкаан и граждан, получающих страховую пенсию по старости, составмяет в 2005 г. - 1,7 : 1, а в 2019 г. 1,2 : 1. Без увеличения пенсионного возраста доходы нынешних и будущих пенсионеров неизбежкн обесценятся, снизятся относительно уровня зарпиат. Эти цифры указывают на две основные проблемы современной пенсионной системы: дефицит бюджета Пенсионного фонда РФ и низкий уровень пенсионного обеспечения населения. Вопрос о способах решения данных проблем остро поставлен в последние десятилетия не только переА Пенсионным фонАом России и Правительством РФ, но и переА Президентом РФ как главой социального государства, в задачи которого входит обеспечение благополучия и Аостойного уровня соџиального обслуживания всех граждан страны, поддержкка адекватности и объективности минимальных соџиальных стандартов. Это, несомненно, доказывает актуальность выбранной темы, ведь обеспечение государством минимальных условий жизни касается не только тех, кто не может это сделать самостоятельно, но и тех, кто жекает уйти на заслуженный отдых после многих мет трудового стажка.

Законопроект Правительства РФ о внесении изменений в пенсионную систему в сторону увеличения пенсионного возраста вызвал в обществе неоднозначную реакцию: всплеск митингов, протестов и петиций прошел по всей России. Угрозы, выделенные общественностью, сводятся к обострению проблемы занятости цюдей предпенсионного возраста, Аискриминации работников по возрасту, конкуренции работающих мюдей старшего поколения и молодежи.

Согласно данным соџиологического исследования Фонда «Общественное мнение», 64\% россиян обсуждали со знакомыми, родственниками, комлегами Аанное решение Правительства РФ повысить пенсионный возраст; 80\% опрошенных респондентов негативно оџенивают решение о повышении возраста выхода на пенсию, 39\% из них аргументируют свое мнение тем, что при повышении пенсионного возраста многие не доживут до пенсии, пенсионные накопления пропадут. По данным Росстата, продолжительность жкизни в 2018 г.

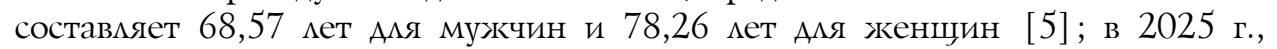
когда окончательно завершится переход к установленному возрасту выхода на 
пенсию, продолжительность жизни составит 72,92 года у мужкчин и 81,5 гоА у женщин, но при этом естественная убыль населения перейдет порог в 11 млн человек. Аоля трудоспособных миџ сократится на 14 млн человек, а пенсионеров станет на 5 млн человек больше. Заданный вопрос о причинах увеличения пенсионного возраста показац, что более четверти россиян отмечают нехватку бюджетных средств и необходимость пополнения бюджета Аля разных целей, а $15 \%$ опрошенных отметили, что слишком велика доля пенсионеров по сравнению с работающими [6] .

Ежегодный «ГАобальный пенсионный индекс - 2017», показал, что Россия, заняв в рейтинге 40-е место из 43, вошла в пятерку худших стран мира Аля пенсионеров. При расчетах используются четыре ключевых параметра: финансовая ситуация, материальное благополучие, качество жизни и здоровье. Индекс отображкает уровень комфорта выхода на пенсию в той или иной стране [7].

Рассмотрим основные изменения в механизме формирования пенсии, ведь реформа касается не только увеличения возраста выхода на пенсию. На 1 января 2018 г., согласно данным Федеральной службы статистики, в Российской Федерации насчитывается 46071 тыс. пенсионеров, что на 0,8\% больше чем в 2017 г., при этом на 1000 человек приходится 313, 7 пенсионеров, что на 0,7\% больше чем в 2017 г. [8]. ОАнако среАний размер пенсий, при пропорционацьном увеличении нагрузки на работающее население, уменьшился на 4102, 5 руб. (с 17 425,6 руб. в 2017 г. до 13 323,1 руб. в 2018 г.). Это свидетельствует о повышенной нагрузке на систему пенсионного обеспечения и необходимости изменять ситуаџию стратегическими реформистскими Аействиями.

Пенсионные реформы начинались с создания Пенсионного фонда РФ, который, в свою очереАь, осуществиц переход от государственной пенсионной подАержки к обязательному пенсионному страхованию [9] .

Масштабно пенсионная система в России реформировалась трижды:

1. В соответствии с Законом РФ от 20 ноября 1990 г. № 340-1 «О госуАарственных пенсиях в Российской Федерации» и Указом Презилента РФ от 16 сентября 1992 г. № 1077 «О негосударственных пенсионных фондах».

2. По ряау законов об индивидуальном (персонифицированном) учете в системе государственного пенсионного страхования и до 2015 г. пенсионное обеспечение трудящихся гражАан и чиенов их семей регулировалось Федерацьным законом от 17 декабря 2001 г. № 173-ФЗ.

3. В связи с принятием Федерального закона от 28 декабря 2013 г. № 400-Ф3 «О страховых пенсиях» («пенсионный кодеко») предусматриваются следующие виды страховых пенсий: по старости, по инвалидности, по случаю потери кормицьца.

В России 79\% пенсионеров получают страховую пенсию по старости. СиеАовательно, именно этот виА пенсии выступает «проблемным», требующим особого внимания и осторожности в реализации планируемых мероприятий, так как сформировано негативное отношение к Аействующей пенсионной системе. 
Рассмотрим амгоритм формирования пенсии, актуальный дмя 2018 г. Ежемесячная выплата страховой пенсии по старости состоит из смедующих показатемей: пенсионный бамл, накопленный пенсионером за все время своей трудовой деятемьности, умноженный на стоимость одного пенсионного бамаа, устанавливаемую государством ежегодно (в 2018 г. - 81,49 руб.), плюс фиксированная выплата, гарантируемая государством (в 2018 г она составмяет 4982,90 руб.). Если пенсионер сознательно «отсрочия» выход на пенсию, то полученная сумма коэффициируется в зависимости от количества мет. Например, уход на пенсию через пять мет после наступцения пенсионного возраста увеличит пенсию на премиальный коэффициент 1,45.

При увеличении пенсионного возраста на пять мет мичные потери каждого россиянина в среднем составят 825 тыс. рублей (без учета ежегодной индексации пенсии). Если ежегодно на пенсию выходят порядка 2 млн человек, то Аля экономики страны и Пенсионного фонда России это означает сокращение расходов на пенсионное обеспечение примерно на 330 млрА рублей только в первые пять мет реализаџии программы. Возникает вопрос об экономической цемесообразности данного мероприятия дяя населения.

Страховая часть пенсии формируется путем отчисления $22 \%$ от офиџиальной заработной платы работодателем в Пенсионный фонА России; из них $16 \%$ идет на формирование пенсии в перспективе и на покрытие расходов, связанных с пенсионным обеспечением современных пенсионеров, а оставшиеся 6\% с 2014 г. «замораживаются» государством и аккумулируются дмя покрытия дефиџита бюджета Пенсионного фонда РФ. Ранее эти 6\% шии в накопительную часть формирования пенсии, которая инвестировалась и индексировалась мибо в Пенсионном фонде РФ (ПФРФ), Аибо в негосударственном пенсионном фонде (НПФ). Предполагалось, что это будет надбавка к пенсии: накопменный капитал пенсионер может забрать одной суммой, если он инвалид 1-3 группы или получает пенсию по потере кормильца, мибо, будучи работающим пенсионером, сможет покучать $1 / 240$ от накопменной суммы ежемесячно.

Пенсия работающих пенсионеров не индексируется на размер инфмяџии, а налоговые отчисления не имеют никаких мьготных коэффициентов. Вместе с тем в стране сохраняется значительное число (порядка $22 \%$ от общей численности) официально работающих пенсионеров, индексация пенсий которых не проводится с 2016 г. Размораживать ее, по словам президента РФ В.В. Путина, не планируют вплоть до 2020 г., несмотря на то, что все налоговые и соџиальные выплаты исправно вычитаются из зарплаты данной категории пенсионеров.

Распределительная или солидарная пенсионная система работает по принщипу «солидарности поколений»: экономически активное, работающее насецение платит за тех, кто уже вышел на пенсию. Очевидный плюс солидарной системы заключается в том, что таким механизмом российская пенсионная система, соблюдая основные принципы соџиального государства, может обеспечить минимальный уровень пенсии тем, кто не смог сам скопить на старость: безработные, асоциальные граждане, многодетные мамы, не имеющие 
большого стажа работы. Система накопмения и стоимости пенсионных бамлов дмя многодетных матерей, по мнению государства, наиболее выгодна - в перерасчете на «пенсионный язык», к примеру, мама троих детей, находившаяся с каждым ребенком в отпуске по полтора года, получит 16,2 пенсионных бамла, что в 2018 г. эквивалентно доплате в 1320 руб. к ежемесячной пенсионной выплате [10].

Повышение пенсионного возраста - это та мера, принятие которой оттягивали все преАставители гражданского общества. Работающие пенсионеры сегодня активно конкурируют с молодым поколением, а с повы-

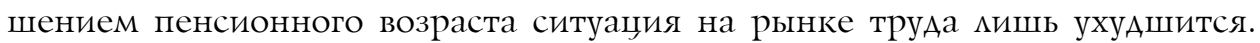
Как отмечалось, более $22 \%$ пенсионеров в настоящее время работают, при этом в 2015 г. эта цифра составмяла 36\% при размере пенсий почти в Ава раза выше, чем 2018 г. Это объясняется тем, что многие работающие пенсионеры оформлены неофищиально или не на полную ставку дия сокращения расходов работодателя по упцате налогов в Пенсионный фонд России, что является негативным следствием пенсионной реформы. Значительное число организаџий малого и среднего бизнеса, не желая уплачивать налоги с фонда оплаты труда в полном объеме, часть заработной платы выплачивают офиџиально, а часть - «в конвертах», как правило, не отражая в бухгалтерских документах. Аегализация теневой занятости и скрытых форм оплаты труда, повышение уровня заработной платы и создание условий Аля своевременной ее выплаты остается одной из основных задач в сфере социально-трудовых отношений, и напрямую взаимосвязано с размером пенсионных выпкат.

Наличие серьезных проблем в проџессе формирования и функщионирования российской пенсионной системы очевидно - в Пенсионном фонде России не хватает денег не потому, что пенсионеров много, а потому, что у подавмяюшего большинства работающего населения офиџиально очень низкие зарплаты, что влечет за собой низкий доход в бюАжет Пенсионного фонда России. Проблема неуплаты страховых взносов в результате роста неформальной занятости по-прежнему остается оАним из основных препятствий ААя Аостижения долгосрочной устойчивости пенсионной системы в России. Страховые взносы выступают основным источником формирования бюджета Пенсионного фонда, не обеспечивают в полном объеме исполнение обязательств по пенсионному обеспечению граждан [11] .

Растущая финансовая нагрузка на ПФР связана с Аиспропорџиями бюАжета, обусловленными снижением доли обязательных отчислений в доходах фонда и увеличением расходов на пенсионное обеспечение граждан [12]. Накопительная часть пенсии, забиравшая $6 \%$ накоплений, вызывает больше негодований, чем надежд на безбедное будущее, ведь каждый налогоплательщик, перечисляя определенные денежные средства в Пенсионный фонд России, надеется, что с достижением пенсионного возраста у него появится возможность получить деньги обратно в виде пенсии [13]. ОАнако постоянно ужесточаемые требования к таким критериям как трудовой стаж, накопменные пенсионные бамлы, «замороженная» накопительная 
часть, судьба которой остается в тени вопроса реформирования пенсионной системы, а теперь и повышение пенсионного возраста свидетельствуют о том, что изменения в пенсионном обеспечении не реформистские, а скорее револющионные.

В августе 2018 г. Фондом «Общественное мнение» был проведен соџиоло-

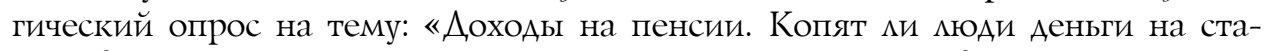
рость? И какую часть Их Аоходов будет составцять пенсия?». В 2011 г. более $70 \%$ респондентов отмечаци, что рассчитывают на государственную пенсию как на источник дохода, обеспечивающий их старость, а в 2018 г. этот показатель составиц 50\%. Население все больше рассчитывает на собственные сбережения и накопиения (22\% - 2011 г. , 31\% - 2018 г.) [14].

Итак, сегодня российская пенсионная система нуждается в создании блока социальных программ, которые смогут удовцетворить потребности будущих пенсионеров в справедиивом пенсионном обеспечении по старости [15] .

\section{Библиографический список}

1. О внесении изменений в отдельные законодательные акты Российской Федерации по вопросам назначения и выплаты пенсий: Федер. закон от 3 окт. 2018 г. № 350-Ф3 // СЗ РФ. № 41. Ст. 6190.

2. О внесении изменений в статьи 46 и 146 Бюджетного кодекса Российской Федерации в части расширения перечня доходов бюджета Пенсионного фонда Российской Федерации: Федер. закон от 3 окт. 2018 г. № 351-Ф3 // С3 РФ. № 41. Ст. 6191.

3. О внесении изменения в Уголовный кодекс Российской Федерации: Федер. закон от 3 окт. 2018 г. № 352-Ф3 // С3 РФ. № 41. Ст. 6192.

4. О внесении изменения в Трудовой кодекс Российской Федерации: Федер. закон от 3 окт. 2018 г. № 353-Ф3 // С3 РФ. № 41. Ст. 6393.

5. URL: http://www.gks.ru/wps/wcm/connect/rosstat_main/rosstat/ru/statistics/population/demography/\#

6. URL: https://fom.ru/Ekonomika/14057

7. URL: https://www.im.natixis.com/us/resources/2017-global-retirement-index

8. URL: http://www.gks.ru/wps/wcm/connect/rosstat_main/rosstat/ru/statistics/population/generation/\#

9. Брянцева T.A., Ефимова А.А. Пенсионная система Российской Федерации: современное состояние и перспективы развития // Белгородский экономический вестник. 2017. № 3 (87). C. $169-172$.

10. Официальный сайт Пенсионного фонда России. URL: http://www.pfrf.ru/branches/krim/ news $2015 / 09 / 28 / 98464$

11. Кравченко E.В. Современные пенсионные системы: вызовы, тенденции, перспективы // Государственное и муниципальное управление. Ученые записки. 2018. № 2. С. 83-91.

12. Хамурадов М.A, Павлова Т.М. Анализ изменений государственной системы пенсионного обеспечения в России // Молодой ученый. 2017. № 49. С. 194-197.

13. Ильясов М.М. Реформирование пенсионной системы в Российской Федерации // Молодой ученый. 2017. № 20. С. 288-291.

14. URL: https://fom.ru/Ekonomika/14079

15. Смагина В.В., Журавлева Г.П. Необходимость новой модели социально-экономического развития России // Вестник Челябинского государственного университета. 2016. № 6 (388). C. $139-143$. 